number of miles traversed by observers to be rather less than in previous counts.

Four species not recorded in any previous count were noted. These were Lesser Scaup at Saskatoon; Chuker Partridge at Battleford, Hawk OwI at Torch River, and Bronzed Grackle at Nipawin. These new records bring the total species recorded in mid-winter in Saskatchewan, in six years of Christmas Bird Counts, to a rather amazing 58.

The Magpie is still the most commonly recorded species, along with the English Sparrow. To offset this, sportsmen should be heartened to hear that our Game Birds - Sharp-tailed Grouse and Huntarian Partridge, and to some extent Ruffed Grouse- seem to be making a fair comback and with luck and a good breeding season in 1948 should be well on their way to recovery after being at a very low ebb during the past few years. At the same time, birds of prey appear to be very scarce.

Winter birds from the north such as the Pine Grosbeak, Evening Grosbeak and Bohemian Waxwing, while apparently well distributed over the province are present in much smaller numbers than last winter, in the more southern parts. Redpolls, usually an abundant visitor, prove to be extremely scarce, there being only 10 individuals reported from three points.

\title{
A Note on Richardson's Ground Squirrel in Saskatchewan.
}

$$
\text { By W. A. Fuller. }
$$

Richardson's ground squirrel, the prairie "gopher", is a well-known animal to most Saskatchewan residents. It is probably the most familiar of our native wild mammals. Such a well-known mammal, however, is apt to be taken too much for granted and consequently, many of the details of its life history go unnoticed.

Zoologically, Richardson's ground squirrel is known as Citellus richardsonii Sabine. Its near relatives in Saskatchewan are two in number, Citelus franklini, the grey or bush "gopher" and Citellus tridecemlineatus, the 13-lined or striped "gonher." More distant relatives are other members of the squirrel family including the red squirrel, chipmunk, ground hog, and in the extreme southwest corner of the province, the black-tniled prairie dog. The proper common name for the genus Citellus is ground squirrel. The term "gopher" should be reserved for the pocket 50 hher which is all too often incorrectly labelled "mole" in Saskatchewan.

A study of the abundance of ground squirrels has been done in Alberta by J.H. Brown of the Alberta Rodent Plabue Survey. His results, based on actual counts of burrows, show that native prairie, the natural habitat of the animals, harbors the greatest number of individuals - about 5,120 per section (Brown \& Ray 1943.) This type is followed by "abandoned" (3, 840) "grassland" $(3,200)$ and "cultivated" (1920.) On irrigated land, flooding keeps the population down to a minimum.

A small amount of information concerning the reproductive cycle was collected in the springs of 1946 and 1947, mainly near Saskatoon. In 1946 , the animals were first seen to be active durinis the last week of March. The first individuals were collected on April 15 - a female carrying 8 embryos. A week later, April 23, two females, each with 10 embryos nenrly at term, were collected. On April 25, two females collected had just given birth to their litters and were nursing. The young were first seen nbove ground at Estevan on May 15, a warm sunny day. The spring of 1947 was genernlly much earlier than that of 1946, however, the first active ground squirrel was "drowned out" 

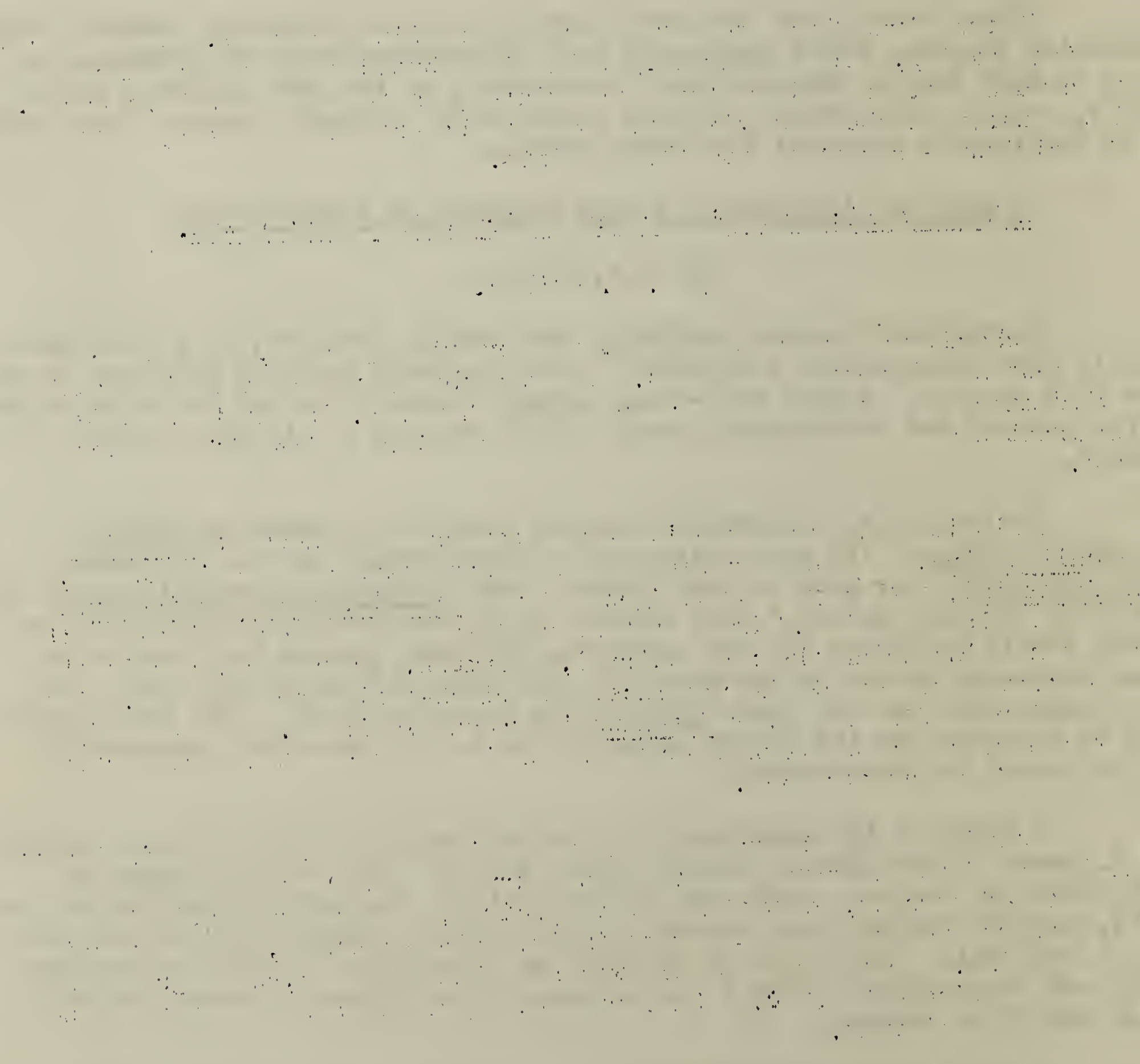
on March 22, a bright sunny day. Three days later, all small ruddles were again frozen over, yet several were seen and one collected. On March 27, (the day the river ice broke at Saskatoon) two femrles were collected and both were in breeding condition. Nearly four weeks later, April 21 and 23, three females collected were pregnant and near term as evidenced by the size of the embryos. This is in close agreement with Brown \& Ray's statement that the gestation period is 27 days. The number of embryos observed in 1947 was smaller than in 1946, and there was evidence that some had died and were being reabsorbed.

Ground squirrels are regularly infested with parasites; fleas, lice and ticks in their fur and various round and flat worms in their internal organs. The fleas and ticks, on account of their disease-transmitting propensities, are reasonably well known, however, much study is still needed on the species of internal parasites, their life histories and general effect on the animals.

The economic importance of the Richardson ground squirrel is overwhelmingly on the negative side. The destruction it wreaks on agricultural crops is too well known to prairie people to need enlargement here. A note on its role as a vector of disease, however, may be of some interest. It may be a reservoir for at least three serious diseases to which man is subject. The first of these, bubonic plague, or black death, has spread through the western United States, into Alberta, and is now known to be in Saskatchewan. It is transmitted from animal to animal and to man by fleas of various species. At least 3 species of fleas, capable of transmittin. plasue, infest Saskatchewan ground squirrels. Humans may also acquire the disease by handlins infected animals. Tularemia, also known to be in Saskatchewan, is transmitted by numerous methods including ticks and handlin infected animals. Rocky Mountain Spotted Fever, also transmitted by ticks, has not yet been reported from Srskatchewan, although it is prevalent in Montana and Alberta.

It should be obvious, then, that the payment of a bounty for tails removed from ground squirrels is an unsound policy from the public health point of view. Other artificial means of control are legion and will not be entered into here. A quotation from Brown \& Ray, concerning the role of natural predators should be of interest, however. "Hawks are the greatest single factor in the natural contest of ground squirrels and every effort should be made to encourage their increase by declaring them a protected bird." Other important nredators are owls, weasels, badgers, coyotes and snakes.

This outline is by no means a complete study and is based mainly on fragmentary observations. It may, however, serve to illustrate that much remains to be discovered about even our comronest mammals, and that chance observations, accurately recorded, may ultimntely prove to be of some value.

Reference: Brown, J.H. \& G. D. Ray, 1943 - The Richardson ground squirrel Cittellus richardsonii Sabine, in southern Alberta: its importance and control. Scientific Agric. Vol. 24, No. 4, Sec. 1943.

\section{ENTOMOLOGY}

TREE \& SHRUB INSECTS

by L.O.T. Peterson

In the survey of tree and shrub insects carried out in the Agricultural Areas of the Prairie Provinces during the 1947 season, more attention was given to middle eastern Saskatchewan than had been possible in preceding years. In this 
